\title{
Influence of Moisture, Temperature and Microbial Activity in Biomass Sustainable Storage. Special Focus on Olive Biomasses
}

\author{
Pedro J Lara Chaves ${ }^{1}$, Julio Terrados Cepeda ${ }^{2 *}$, Francisco J Gallego Álvarez ${ }^{2}$ and Manuel J Hermoso Orzáez ${ }^{2}$ \\ ${ }^{1}$ Bioland Energy S.L, Spain \\ ${ }^{2}$ Department of Engineering Projects, University of Jaen, Spain
}

Submission: July 31, 2020; Published: August 11, 2020

*Corresponding author: Julio Terrados Cepeda, Universidad de Jaen / Campus Las Lagunillas, Edificio A3 / 23071 Jaen, Spain

\begin{abstract}
Biomass is a renewable energy source that, due to its high seasonality, needs to be stored, handled and managed in suitable conditions for its optimum use. Sustainable storage is, therefore, a key process in which biomass can lose much of its qualities as fuel. The article presents an exhaustive bibliographic review of the factors that affect the quality of biomass during storage and the interactions that occur among them. Humidity, type of product, granulometry, size of the stockpile, airflow, temperature, and microbial action are analysed as the main factors affecting biomass during storage, and the results are compared with the tests that have been carried out on biomass from olive groves and olive oil industry. Recommendations are presented so that, using a correct storage method, losses, degradation and self-ignition risks are reduced and the energy quality of the fuel could be improved, taking advantage of the storage process to optimize the net energy yield.
\end{abstract}

Keywords: Biomass storage; Self-heating; Renewable energy; Olive pruning biomass

\section{Introduction}

Since prehistoric times, humans have used wood and other organic waste as a source of energy. This biomass has been used as fuel, with the name of biofuel, or in general as bioenergy. Hence, biofuels may include a large group of different fuels, which all are originated from biological resources. These biofuels include, among others: wood, bark, chips, sawdust, pulp-mills, straw, waste and peat.

However, the use of this biomass as fuel is not always easy, since biomass is a very heterogeneous renewable energy source that can have different structures and house different compositions of matter. This makes its handling complicated and must be addressed in different ways depending on the type of biomass being used, the conditions in which it is worked such as climate, the spaces and surfaces, and also on the techniques used to store the product, conserve it, dry it and mechanize it. All these conditions will eventually influence the energy quality of the biomass.

Most of the studies carried out on the energy use of biomass agree that the storage stage is a fundamental phase given that during it there are alterations in the quality of the product and loss of dry matter, which will be greater the worse the storage is carried out [1].

Therefore, the use of a good storage method will greatly reduce losses [2], reducing in turn the economic losses associated with energy use of biomass, as noted in the study by Ronald Gonzalez [3]. On the other hand, other studies show that the storage of biomass in the field can be used to improve fuel quality. For example, the study by Shuva Gautam [4] shows that the quality of wood changes during storage and also its net energy yield. They assessed the main fuel attributes (moisture content, gross calorific value and ash content) during the storage of logging residues, and showed that the storage regime played a significant role on the fuel quality of such residue, and that proper storage may improve the fuel quality and net energy yield, leading to an overall cost reduction of the biomass feedstock.

Thus, the objective of this study is to make a bibliographic review of those factors that may affect the quality of biomass during storage, analysing the interactions that occur between them, and establishing their degree of importance. Likewise, the results of this review will be compared with those obtained 
from field tests carried out with olive biomass in an electricity generation plant in the south of Spain.

\section{Main Factors Affecting Biomass Storage}

The storage of biomass in its various configurations (chips, pellets, ...) has been investigated at various levels over the last few years. These researches have brought to light the existence of a wide range of factors that may affect the quality of biomass during storage.

Good quality biomass must be homogeneous, low in moisture content, low in ash content, and with little foliage or particles, and these factors could be altered by storage conditions such as: shape, location, duration and weather conditions [5].

Most of the authors [4,6-10] agree that the main factors that determine the loss of quality of biomass during storage are the following: type of material (hardwood, softwood, leaf and/or bark fractions), size of the stockpile, initial humidity, degree of heating and self-ignition risk, particle size and distribution, stockpile ventilation, climatology (ambient temperature and humidity), wind speed and direction, and the action of microorganisms (microflora, insects and bacteria). All these factors interact with the chemical composition of the biomass and most are related to each other.

Furthermore, Gold and Seuring analysed the most relevant issues of supply chain management and logistics for bio-energy production [11] and among their findings they assure that the main risks to be minimized in a storage system are biomass quality degradation and dry matter losses.

The study developed by Emery \& Mosier [12] focus on dry matter losses and show that the main losses are associated with moisture content, exposure to rain and contact of the pile with the soil. They assert that indoor dry storage generates the smallest losses, while outdoor storage allows greater losses up to $16 \%$, with the potential for extremely high losses of over $36 \%$. On the other hand, the Gold and Seuring [11] investigations broaden this range of factors, proposing that there are others that affect the cost loss of the product during storage, such as location, type of storage and the number of manipulations carried out on the biomass.

The location of the storage can be placed in areas close to the harvest or collection field, on the road or some more specific centres such as port silos. While the type of storage can vary from open-air storage to closed-roof storage with fans.

The choice of storage type will depend on the environmental climate and the biomass processing stage. Studies by Thornley [13] and Rentizelas et al. [14] highlight that for humid climates and Mediterranean climates, respectively, covered facilities can be assumed, usually for short rotation storage.

Other factors affecting storage will be the volume and density of biomass to be stored [11], the duration of storage phase [15], and the proportion of wood, bark or foliage $[16,17]$.

According to existing research on biomass storage, and as we will see in the following sections, it can be seen that the main factors affecting the quality of biomass during storage are the initial moisture, granulometry, herbaceous component and the size of the stockpile. Moreover, within the factors that appear by causality of these, we must highlight the temperature as the main factor to be taken into account, as it is the cause of self-ignition processes.

\section{Analysis of Physical-Chemical Factors of Biomass}

\section{The influence of humidity and the activity inside the stockpile}

Most of the existing studies reveal that the physical-chemical factors are linked to each other and that the variation in the parameters of one of them causes changes in the rest. According to M Pettersson [5] the most important characteristic of biomass is its moisture content, since it affects the calorific value, storage properties and transport costs that finally determine the price of biofuel.

Biomasses with high moisture content have a higher activity inside the pile during storage. If no heat exchange is generated between the interior and the exterior during storage, the increase in temperature increases the risk of internal reactions and can cause self-ignition [18].

The humidity of the air also influences the moisture content of the biomass. Changes in humidity are governed by the equilibrium relationship between wood and air. Compared to humidity, air temperature is not such a significant factor. If it can be when it comes to storage for short periods, however, other factors are more important when it comes to storage for longer periods, as shown by the studies of Lin \& Pan [19].

There are also other factors associated with biomass moisture that can favour degradation and self-ignition processes during storage. In the Yasuhara study [20] it was concluded, among others, that not only the water content of the biomass was the cause of self-ignition, but also the initial temperature and particle size are indicative factors.

Most authors therefore agree that the moisture content of the biomass is the main factor that generates temperature increases within the stockpile. Moreover, this increase in temperature is a determining factor in internal reactions and risk of self-ignition.

Humidity is also considered by Hakkila [21] as the most influential factor. In his analysis, based on the energy and climate strategies implemented in Finland, he ensures that moisture is the most important factor in the quality of wood biomass because it influences: 
a) Price: the higher humidity is, the lower is biomass price.

b) Calorific Power: higher humidity implies lower calorific value.

c) Crushing and/or handling: depending on the type of machinery, it will be easier to grind or handle a dry or wet product.

d) Transport: less humidity, less weight transported in the same truck.

e) Storage: higher humidity, greater degradation of biomass properties throughout the storage period.

f) Energy production: loss of biomass properties directly affects plant energy production.

g) Profitability: negative effects on production are transferred to profitability.

h) Emissions: higher humidity implies greater possibilities of incomplete combustion and carbon monoxide emissions.

Other studies, such as the one conducted by Towey et al. [22], also conclude that biomass with moisture content below $20 \%$ are stable and not fit for microbial consumption, regardless of environmental temperature, while biomass with moisture contents above $20 \%$ may degrade and would not be put into longterm storage.

In addition, the moisture content increases with decreasing particle size and increases with time of contact with air. Therefore, granulometry, height and stack size are very important factors in this process [6,23].

Another determining factor is the storage duration. Various studies analyse moisture variation over time $[8,24]$. In relation to this variation in humidity, the storage of biomass small piles during medium-long periods (up to 9 months) may recover up to $4 \%$ of energy through loss of humidity. In large piles the opposite occurs, energy is reduced by $3 \%$ and in a shorter period (up to 6 months). The greatest losses occur in large stockpiles and in those where the particle size is small. The ideal height for non-compacted woodpiles would be 6 to 16 meters, while for compacted piles it would be 4 to 12 meters.

Air temperature is another major factor in the biomass drying process. Several authors have studied the relationship between environmental factors and the humidity of the stored biomass. Pari et al. [7] analysed the relationship between wood moisture content, air temperature, air humidity and rainfall, concluding that air temperature affects wood moisture content by $70 \%$, while air humidity and rainfall are barely significant. Generally, weight loss is highly temperature related. The weight loss ratio is $1-2 \%$ per month [25].

Zabetti et al. [26] also highlights how the ISO classification maintains as biomass quality parameters those strictly related to the energy content of the wood chips, such as moisture content, while it is more tolerant in terms of particle size classification.

\section{Factors affecting temperature increase and risk of self- ignition}

As it has been commented, although it is a factor caused by the combination of others, it is worth to analyse the temperature and its relationship with the other factors. According to Ferrero et al. [27], who developed a model for predicting the heating-up and the possible self-ignition of large-scale wood piles, the increase in temperature inside biomass stockpiles can be generated by three different causes: by oxidation reactions inside the pile, by exothermic condensation/adsorption processes originated inside the stockpile, or by microbial processes.

According to a study carried out by Thörnqvist [28], the temperature in small piles, up to $120 \mathrm{~m}^{3}$, is kept approximately at ambient temperature, while in larger piles, up to $600 \mathrm{~m}^{3}$, the temperature is usually between 10 and $30^{\circ} \mathrm{C}$ above ambient temperature in the centre of the pile. However, this behaviour may be influenced by external conditions. In a study conducted in Canada [29] in which birch biomass was stored in different forms, it was observed that, due to good air flow conditions, there was no increase in temperature in the wood piles, following the pattern of ambient temperature.

Is worth mentioning that the number of woody biomass related accidents are mainly related with temperature increase and self-heating. Krigstin et al. [30] conducted a compilation of incident reports involving biomass storage, and such study has revealed that these potential hazards continue to be a major concern in the bioenergy sector. They also state the need of realtime pile monitoring in order to provide instant temperature data on to properly control such incidents.

In the case of the self-heating of large scale storage of biomass, it has been reported the influence of chemical oxidation, microbiological processes as well as the effect of the evaporation and condensation of moisture as mayor factor increasing risk of ignition [31]. In such cases, moisture content has to be controlled and inside temperature needs to be monitored as there is evidence that periodic behaviour occurs in large stockpiles because of the interaction of the evaporation and condensation of water together with chemical reaction.

Other factors, such as the content of bark or leaves that means higher herbaceous component, may also increase the temperature during storage. In the study carried out by Anheller [32] with data from the storage of pine bark in both small and large stockpiles, the stockpiles suffered a high and rapid temperature increase, reaching $60^{\circ} \mathrm{C}$ in a few days in small stockpiles and above $70^{\circ} \mathrm{C}-75^{\circ} \mathrm{C}$ in large stockpiles.

Moreover, the temperature distribution is usually not homogeneous within the stockpile. Buggeln [33] showed temperature distribution in stockpiles 4.5-6 meters high. The top and centre of the stockpile reached temperatures above $60^{\circ} \mathrm{C}$, while the bottom of the stockpile never exceeded $50^{\circ} \mathrm{C}$. Thus, heat loss occurs in the upper and lateral parts of the stockpile. 
On the other hand, air circulation and storage duration are factors described by Gislerud \& Grønlien [34] as determining factors in the temperature increase inside the stockpile. In the analysis carried out on a wood chips stockpile of about $500 \mathrm{~m}^{3}$ it was observed that the temperature increases over time in all the measurements and, depending on the area where the measurement is made, the temperature increases at some points much more than at others as a function of the circulation of the existing air.

These factors have also been proven in other studies. Hogland \& Marques [8] studied the temperature increase of wood piles to the point of self-ignition and analysed the temperature variation at different points from the surface to the inside of the stockpile. The highest temperature was measured in the internal-high parts of the collection, passing in the first month from $49^{\circ} \mathrm{C}$ to $73^{\circ} \mathrm{C}$. Then it increased very slowly and progressively from $66^{\circ} \mathrm{C}$ to $90^{\circ} \mathrm{C}$ on average. In this way, it was maintained for 5-6 months until a strong wind propitiated a self-combustion, increasing the temperature drastically up to $246^{\circ} \mathrm{C}$ in 24 hours. These high temperatures over long periods of time propitiate self-ignition of the biomass. Yasuhara et al. [20] found that biomass can burn on its own if subjected to temperatures above $140.5^{\circ} \mathrm{C}$ and exposed to it for 270 minutes. This drastic increase in temperature was also experienced in a stockpile of $5,000 \mathrm{~m}^{3}$ analysed in the study carried out by Löwegren [35] in which the temperature increased in several days to almost $300^{\circ} \mathrm{C}$, when it had been stored for about 4.5 months.

There is no exact self-ignition temperature of the biomass. It depends on the type of material, catalyst action and oxygen input. One of the main reasons for self-ignition is the permeability of the product, since it can retain water in the interior that makes heat and temperature transfer to other parts [6]. The first signs that the stockpile is in poor condition and that there may be self-ignition risk is the presence of strong odours and high temperatures.

The Frank-Kamenetskii method, reviewed by Per Blomqvist and Bror Persson in detail [36], assumes that self-ignition process occurs if the material is sufficiently porous and reactive to allow availability of fuel and oxygen throughout the whole selfheating process. It defines a characteristic and critical length of the pile above which the material will self-ignite as a function of the ambient temperature, but no account is taken to moisture transport and the accompanying phenomena of hydrolysis, evaporation and condensation. Blomqvist and Persson assert that the Frank-Kamenetskii theory is best suited for application on materials that do not have excessive moisture content and where the reactions can be sufficiently well described by a single order reaction.

In general, there is a great increase in temperature in the internal and superior areas of the pile. This is due to the fact that with the passage of time both the humidity of the biomass and the microbial activity increase the temperature inside the collection. If the air circulating from the outside of the stockpile to the inside does not reach the internal areas, it does not provide the necessary cooling and self-heating may take place. In addition, if the air ambient temperature is high, it contributes to the acceleration of the temperature increase. In woodpiles, temperature and humidity are transported by the flow of air to the more internal-high parts of the collection, increasing the temperature by conduction and the humidity by condensation of gases and vapours [8]. In the central parts of the stack, the temperature increases rapidly during the first weeks, then stabilizes and finally decreases progressively [9].

Due to the circulation of air through the pile during the drying process, a "chimney effect" is produced in the upper areas. The air enters the pile cooling the product, but reheating as it moves through the collection. The air carries away the water contained in the materials, thus creating a flow of moist and warm air. This makes the water flow vertically up to the top of the collection where it undergoes a strong heating and is expelled to the outside in the form of steam. This reheating is favoured by the microorganisms dragged by the airflow and, if the air circulation is vigorous, there may be penetration into the particles and a heat transfer effect may occur [9,37]. Heat can have a positive effect if the dissipation becomes homogeneous, as it can decrease the humidity to all parts of the pile and increase its energy power, but with the "chimney effect" the inner parts dry out while outer and higher parts wet out [6].

These effects can be seen in Figure 1, which was taken from the tests carried out by the University of Jaen, where the action of the airflow through a biomass stockpile is observed.

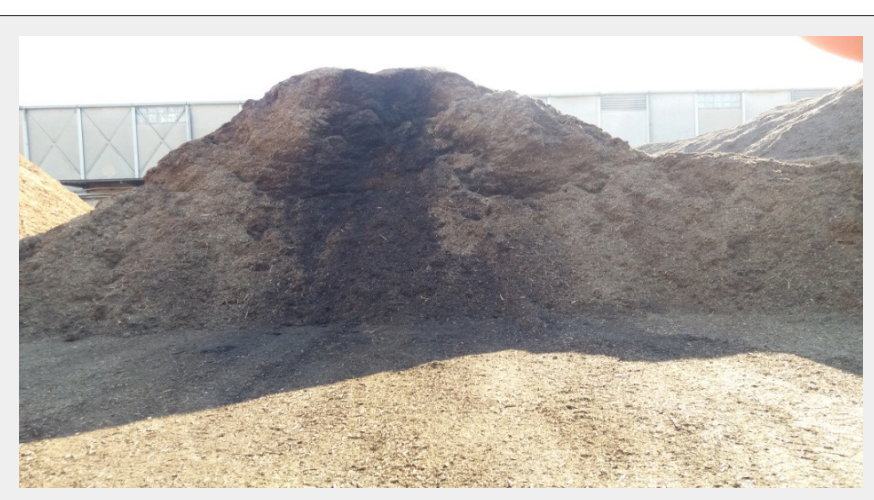

Figure 1: Biomass collection where the zone of the pile heated by air circulation is observed. 


\section{The effects of particle size, compaction and stockpile} size

The height and compactness of the piles also has a great effect on temperature variation. The higher the pile height, the greater the compaction and therefore the ventilation is lower, the temperature increases, and spontaneous combustion may occur. On the other hand, smaller piles are poorly compacted and their temperature does not usually exceed $54^{\circ} \mathrm{C}$, although this favours auto-oxidation [38].

The increase in the compaction degree of the biomass pile prevents air circulation and has two opposing effects [39]: the lack of heat evacuation by convection, which produces heating, and the decrease in biological activity, which produces a decrease in temperature.

Hence, compaction influences the permeability of the pile against an airflow. This permeability, according to Ernstson [40], depends on both the porosity of the material and the compaction of the pile. On the other hand, the interaction between the environment and the stockpile will be greatly influenced by the compaction of the pile. Gautam [4] compares hardwoods and softwoods, where hardwood stockpiles have a larger empty space than softwood stockpiles. The more pronounced branching of hardwoods allows for less compaction, therefore, there is a greater percentage of free space which implies less resistance to air passing into the stockpile. In softwoods, the voids are smaller and therefore there is greater resistance to airflow, especially when the stocking form is not in a row. It is also noted that the shape of the stockpile has a significant effect on the moisture content of the stockpile. Such study shows that stockpiles in rows have a larger area exposed to ambient air, which favours drying, cooling and moisture loss.

In short, the granulometry of the material affects the circulation of air through the collection and conditions the increase in temperature. According to the study carried out by Ferrero [27], in which the factors that intervene in self-ignition during the storage of chipped wood stockpiles are analysed, it is observed that the temperature increases to a greater extent and is maintained over time, reaching over $70^{\circ} \mathrm{C}$, in stockpiles with finer granulometry. While, in larger granulometry stockpiles, temperatures do not exceed $45^{\circ} \mathrm{C}$ and after less than one month, it begins to fall and equalize to the ambient temperature.

This temperature increase has also been analysed by Fuller [41] in a study where he obtains a sequence of temperature increase in biomass stockpiles. It is based on the fact that the main factors that produce this temperature increase are the compaction and the height of the pile. It is also noted that the living cells are in the bark, foliage and wood. Therefore, when the tree is crushed these cells (Parenchyma) breathe in an attempt to heal the tree and can live up to six months depending on conditions. In this process, oxygen is consumed, and heat is released, generating good conditions for the growth of bacteria. For this reason, several authors agree that, for crushed products, the size and height of the pile must be smaller in order to reduce the risks of self-ignition $[7,34,38,42]$.

Other authors also focus on the effects of particle size on ventilation and self-ignition risks. Ramirez et al. [43] considers that the humidity of the product, the size of the particles and the place where the product is stored significantly affects its flammability and there are significant differences in storage caused by the difference in particle size. Furthermore, the greater porosity of the collection composed of larger particles improves the natural aeration of the storage [44].

The effect of granulometry was also analysed in a study developed by Anheller [32] where two biomass storages of different sizes were carried out. One of the piles was made of recovered wood $(6.5 \mathrm{~m}$. height $\times 50 \mathrm{~m}$. length) and another was made of bark ( $4 \mathrm{~m}$. height $x 15 \mathrm{~m}$. length). It was observed that in the first pile there were no significant changes in temperature and humidity. While in the collection of bark there was an increase in temperature in the first days, reaching up to $75^{\circ} \mathrm{C}$. In the bark piles there are more losses due to moisture content and particle size.

\section{Microbial Activity and its Relation with the Temperature of the Stockpile}

Temperature is not the only indicator of deterioration and loss of dry matter. It is also necessary to take into account the presence of fungi, bacteria and microorganisms. Therefore, the chemical composition of wood is very important, especially if it is to be stored for long periods of time [44].

Different types of bacteria can be found in the same pile of wood, since, within the same pile, the temperature also varies according to whether the zone is upper, lower or medium [45]. Depending on the temperature of the different zones of the collection, a series of microorganisms or others will act: Cryophylls, between $0^{\circ} \mathrm{C}$ and $20^{\circ} \mathrm{C}$; Mesophylls, between $20^{\circ} \mathrm{C}$ and $30^{\circ} \mathrm{C}$; and Thermophiles, between $35^{\circ} \mathrm{C}$ and $70^{\circ} \mathrm{C}$.

The composition of the biomass also influences the presence of microorganisms. The presence of lignin hinders the action of bacteria on cellulose and hemicellulose to complete pentose. Delignification is more difficult in soft woods and access to cellulose chains is a problem. Hardwoods have higher acetyl (acetic acid) and higher levels of pentose, which favours bacterial activity. In softwoods, the low level of pentose can prevent rapid initial $\mathrm{pH}$ changes, although high lignification can reduce the efficiency at which hemicellulose could produce xylenes.

The study conducted by Gautam [4] shows that softwoods produce less moisture content than hardwoods, due to their chemical and anatomical composition. In hardwoodshemicellulose constitutes $25 \%-40 \%$ compared to $25 \%-30 \%$ in softwoods. Hemicellulose is the most hygroscopic component of cell walls, followed by cellulose and lignin. Because of this, hardwood cell walls will have more potential accumulation sites for water, which 
will favour moisture increase and bacterium action.

Organic matter is broken down or decomposed by bacteria or microorganisms to $\mathrm{CO}_{2}, \mathrm{H}_{2} \mathrm{O}$ and energy. This released energy is used by the cells for their metabolic process [18]. The much more common storage of chips in the open-air leads to greater importance of chip size and the proportion of fine particles. For the finer the chips, the more the air movement will be altered and the less heat dissipation from the stockpiling will occur. Because of the heat produced in the stack, there will be more fermentation and more pentose will be produced from cellulose and hemicellulose, which would produce lactic acid, acetic acid, water and carbon dioxide. However, if the particles are larger, there is more aeration inside the collection. This aeration also makes more oxygen available within the collection, which is an important requirement for the biological and chemical decomposition process [44].

When wood is cut or crushed, living cells tend to repair the damage by increasing respiration and thus increasing the heat released. In compacted stockpiles there is much more wood, which means more heat to dissipate. This heat generates good conditions for the development of bacteria. The cutting and fragmentation of wood facilitates the process of decomposition and degradation, as they have more surface to be attacked by microorganisms. Between two and five centimetres, it is the ideal size. The presence of thick branches or lignified elements can inhibit, slow down and delay the fermentation process [46].

The compaction of the collection will depend largely on the granulometry of the material. Greater granulometry means greater contact surface for the proliferation of fungi, although on the other hand the effect of compacting decreases the passage of air [47]. In ventilated piles, the risk of self-ignition and moisture content are reduced, but a favourable environment is created for the establishment and growth of different species of fungi despite the low humidity [48].

A parameter that evidences the changes that are taking place in the biomass by effect of the fungi and microorganisms is the colour that such biomass presents. Eslyn [45] studied the colour variation of biomass depending on how fermentation progressed, and differentiated between:

a) Light brown colour - medium: when there had only possibly been an oxidation of the surface of the biomass.

b) Dark brown colour: when a soft rot begins to occur.

c) Blue spots: there is more rotting and more action of bacteria, fungi and microorganisms.

d) Bleached chips: there is more rotting which also affects the hard parts of the wood.

In the tests carried out at the University of Jaen it has been possible to verify this evolution of the colour in the superficial part of the biomass stockpiles which allows us to know whether or not there is bacterial or microbiological action:

a) Bronzed colour: there is hardly any biological action (Figure 2).

b) Color White: action or appearance of fungi (Figure 3).

c) Colour Black/Brown/Yellow: action of different microorganisms (Figure 4 \& 5).

Figure 2: Non-fermented biomass. [Own elaboration]
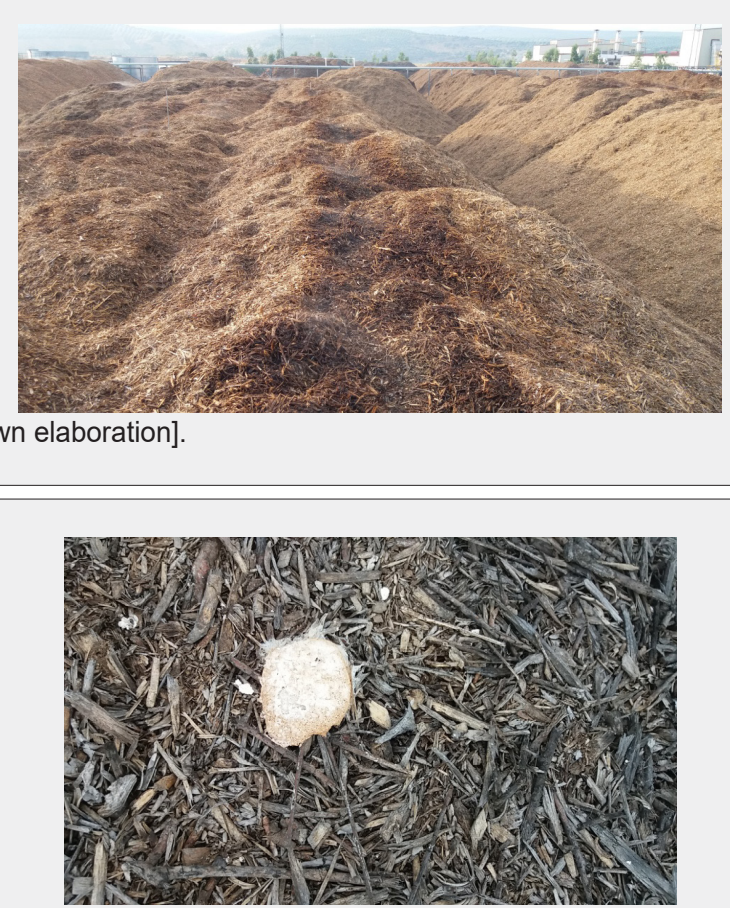

Figure 3: Appearance of fungi in the internal layers and on the surface of the collection. [Own elaboration]. 


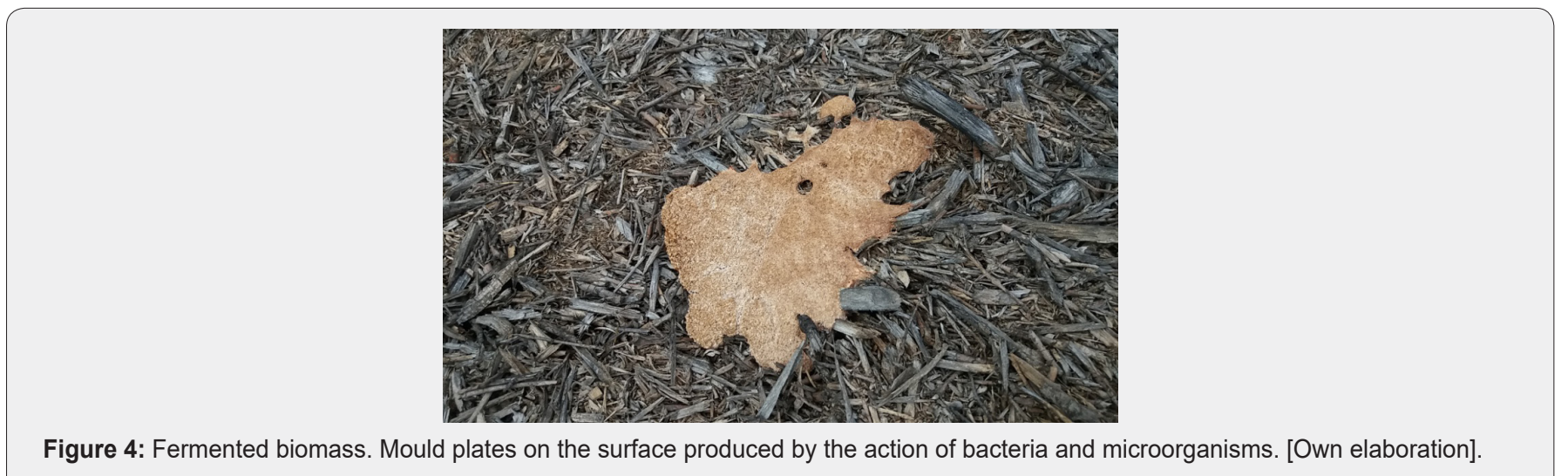

Figure 4: Fermented biomass. Mould plates on the surface produced by the action of bacteria and microorganisms. [Own elaboration]

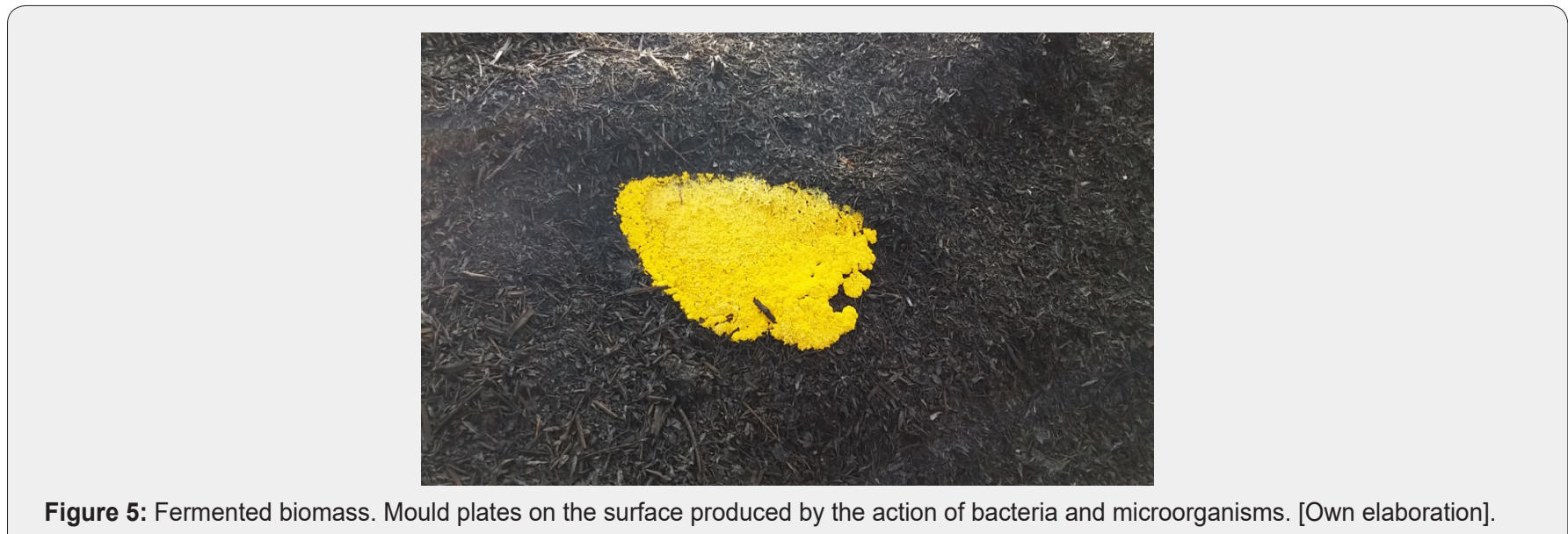

Thermogenic processes occur during storage, mainly due to the action of living wood cells, the biological action of wood and the phenomena of chemical oxidation and acid hydrolysis of cellulose components [9].

Normally, the initial temperature increase in a biomass stockpile occurs because of biological action. Bacteria, in the right environment, produce fuel degradation by generating heat, carbon dioxide and water. They can act up to $60^{\circ} \mathrm{C}$ but at higher temperatures, their activity decreases rapidly. The most important are the fungi, and among them, the fungi that usually act on the biomass are the xylophage's fungi and blue fungi. The former produce greater degradation and at a faster rate. They normally live in temperatures between $20^{\circ} \mathrm{C}$ and $40^{\circ} \mathrm{C}$ but they can survive at temperatures of $-2^{\circ} \mathrm{C}$ and above $50^{\circ} \mathrm{C}$. Furthermore, fungi have to work in the presence of water.

On the other hand, bacteria tolerate a wide range of temperatures, reaching up to $75^{\circ} \mathrm{C}[6,8]$. When the temperature exceeds $40^{\circ} \mathrm{C}$ chemical reactions begin, and at $50^{\circ} \mathrm{C}$ the most important ones begin to take place. Biological activity increases the temperature to levels at which chemical action takes part [49]. In wood storage, if the wind hits a stockpile, or part of it, that is at temperatures close to $80^{\circ} \mathrm{C}$, oxidation processes accelerate and the temperature may increase very rapidly [8].
If biomass is stored uncrushed, little heat develops. In this case, there is no friction between particles, the specific area of action of the microorganisms is smaller and the cells of "Parenchyma" have very little oxygen for their respiration [9].

According to studies conducted by Emery et al. [12] fermentation, which reduces the $\mathrm{pH}$ of the pile, occurs during the first week of the first month of storage. After this, the collection will be relatively stable for up to one year with minimal losses if good storage practices are followed. Therefore, losses are believed to be resistant to variations in storage duration.

In addition, microbial activity slows down in acidic media with $\mathrm{pH}$ less than 6 . Therefore, it is advisable to maintain low $\mathrm{pH}$ levels so that there is no microbiological action. To prevent microbial action, fungicides can be added but this could lead to environmental and legislative problems [46]. Another solution to mitigate biological activity is to keep humidity below the saturation point of the fibre, which is $23 \%$ [8]. It is also possible to increase the temperature up to $70^{\circ} \mathrm{C}$ or more, but in this case the quality of the wood may decrease.

Decomposition effects are more likely to occur when the product contains leaves, bark or foliage [50,51]. Wood chips have a long surface area that allows bacteria to colonize. Forest residues 
and barks contain high concentrations of minerals and inorganic elements that could also improve microbial activity. Stockpiles of products with high bark or herbaceous content begin to undergo chemical and biochemical reactions before three or four weeks of storage [1,21].

The Emery and Mosier study [12] assumes that dry matter loss is primarily the result of biological degradation and suggests that renewed microbial activity can cause losses of $1.5 \%$ of the total when more than 48 hours elapse from product storage to consumption. Normally, the balance between quality improvements due to biomass drying and dry matter losses due to bacterial action is usually negative. They will depend on the humidity and the storage time duration [17].

Other studies [5] also contrast that the main losses of dry matter are caused by bacterial action and the loss of product during handling and transport. In some cases [9] wood losses have been estimated in the range of $0.5 \%-1 \%$ in cold and temperate climates, while they would be $0.75 \%-3 \%$ in hot and humid climates.

At higher temperatures, between $35^{\circ} \mathrm{C}$ and $50^{\circ} \mathrm{C}$, the concentration of gas, generated inside the stockpile and emitted to the outside, increases significantly. At $35^{\circ} \mathrm{C}$, the concentration of $\mathrm{CO}$ and $\mathrm{CH}_{4}$ are always high, while that of $\mathrm{CO}_{2}$ is only high in some cases. This is due to microbial activity [46]. Therefore, the storage temperature is a crucial factor during the storage of fresh waste. High temperatures lead to high concentrations of gases and the concentration of gas has a high relationship with the loss of dry matter from the stored product [52].

Contrast of Results in Tests Carried out with Olive Biomass

The University of Jaén, in collaboration with the company Valoriza, has carried out a series of tests with different types of biomass from the olive grove and olive oil sector, and it has been possible to verify in them the parameters analysed previously.

It should be highlighted that more than nine million hectares of olive trees are cultivated throughout the world, especially in Mediterranean countries. As an essential operation, the pruning of olive trees produces an enormous amount of biomass that, in most of the cases, lacks industrial applications and must be eliminated annually from the fields to prevent the spread of plant diseases. The biomass produced by pruning is usually eliminated by direct combustion or by chopping and dispersal in the field [53].

The importance of the biomass potential of olive groves in the south of Spain, especially in the province of Jaen, is enormous. Several studies have quantified the production of biomass as a by-product of olive cultivation in a range of between one and five tonnes per hectare, which means an annual production of about 800,000 tonnes per year [54]. This is the main justification for the research work that is being developed at the University of Jaen in order to optimize and valorise energy production based on the use of these biomasses.

Tests were carried out at Valoriza Energía's facilities, located in the province of Jaen (Spain). This biomass power plant has more than four useful hectares of biomass storage and consumes nearly 120,000 tons of different types of biomass per year. With a nominal power of $16 \mathrm{MW}$, combustion takes place on a vibrating grate cooled by water and by the combustion air itself. Although this plant is designed so that its biomass consumption can be composed by $100 \%$ of olive pruning, in this plant poly-biofuel mixtures are also used.

The general characteristics of olive grove biomass are shown in Table 1.

Table 1: Characteristics of olive grove biomass.

\begin{tabular}{|c|c|c|c|c|c|}
\hline Biomass & Moisture (\%) & PCI (Kcal/Kg) & Herbaceous Content & Ashes & Volatile \\
\hline Olive pruning & $35 \%$ & $3.200-3.500$ & High & High & How \\
\hline Olive leaf & $>40 \%$ & $2.600-2.900$ & Very High & Very High & High \\
\hline Olive pomace & $<15 \%$ & $3.700-4.100$ & Very Low & Low & High \\
\hline Olive stone & $<15 \%$ & $4.000-4.300$ & Very Low & \\
\hline
\end{tabular}

The tests on biomass storage processes were carried out between November 2015 and April 2017. We worked with 33 stockpiles of biomass that were stored between 20 and 452 days, before being processed in an electricity generation plant. The main characteristics of such stockpiles are accounted in Table 2, including storage input date, total storage time, initial humidity, mean temperature, weight and higher heating value.

Tools used for data collection were the following:

a) Initial Humidity (\%). Moisture analysis was carried out according to UNE-CENT/TS 14774-1/2/3, by drying the sample in oven at $105^{\circ} \mathrm{C}$ up to constant weight.

b) Initial Higher Heating Value (HHV) (kcal/kg). The HHV was analysed by means of a PAR 6000 Calorimetric Pump according to Standard UNE-EN-14918.

c) Initial Lower Heating Value (LHV) (kcal/kg). According to the HHV data obtained in the calorimetric pump and according to the UNE-EN-14918 Standard. 
d) Temperature control by means of a FLIR ix series Extech IRC30 Thermographic Camera. e) Temperature evolution inside the collection. By means of a temperature probe placed in the stockpile that informed of what was happening inside the collection.

Table 2: List of stockpiles tested.

\begin{tabular}{|c|c|c|c|c|c|c|c|}
\hline Ref. & Product & $\begin{array}{l}\text { Storage Input } \\
\text { Date }\end{array}$ & $\begin{array}{l}\text { Storage Time } \\
\text { (Days) }\end{array}$ & $\begin{array}{l}\text { Initial Humidity } \\
\text { (\%) }\end{array}$ & $\begin{array}{c}\text { Mean Temperature } \\
\left({ }^{\circ} \mathrm{C}\right)\end{array}$ & $\begin{array}{l}\text { Weight } \\
\text { (Ton) }\end{array}$ & $\begin{array}{c}\text { HHV (kcal/ } \\
\text { kg) }\end{array}$ \\
\hline 51 & Crushed pruning olive tree & $2 / 3 / 2016$ & 174 & $27 \%$ & 82,7 & 1279,7 & 4553,6 \\
\hline 52 & Crushed pruning olive tree & $29 / 01 / 2016$ & 136 & $29 \%$ & 87 & 899,16 & 4589,3 \\
\hline 57 & Crushed pruning olive tree & $17 / 03 / 2016$ & 56 & $25 \%$ & 65 & 1010,02 & 4592,2 \\
\hline 60 & Crushed pruning olive tree & $29 / 03 / 2016$ & 405 & $23 \%$ & 54 & 1399,88 & 4539,2 \\
\hline 64 & Crushed pruning olive tree & $6 / 4 / 2016$ & 447 & $25 \%$ & 34 & 995,12 & n.a \\
\hline 65 & Crushed pruning olive tree & $11 / 4 / 2016$ & 371 & $24 \%$ & 42 & 3864,5 & 4509,2 \\
\hline 66 & Pre-Crus. pruning olive tree & $12 / 4 / 2016$ & 452 & $21 \%$ & 45 & 1625,82 & 4416,1 \\
\hline 67 & Crushed pruning olive tree & $14 / 04 / 2016$ & 31 & $23 \%$ & 65 & 279,42 & 4509,2 \\
\hline 68 & Crushed pruning olive tree & $18 / 04 / 2016$ & 139 & $23 \%$ & 84,6 & 1090,68 & 4389,2 \\
\hline 69 & Crushed pruning olive tree & $20 / 04 / 2016$ & 91 & $25 \%$ & 84,6 & 1141,5 & 4680,6 \\
\hline 70 & Pre-Crus. pruning olive tree & $20 / 04 / 2016$ & 105 & $11 \%$ & 85 & 1434,42 & 4416,1 \\
\hline 71 & Crushed pruning olive tree & $26 / 04 / 2016$ & 30 & $21 \%$ & 45 & 785,74 & 4395,7 \\
\hline 73 & Pre-Crus. pruning olive tree & $6 / 5 / 2016$ & 440 & $17 \%$ & 47,8 & 650,62 & 4627,8 \\
\hline 74 & Crushed pruning olive tree & $10 / 5 / 2016$ & 391 & $26 \%$ & 30 & 1574,34 & 4469,6 \\
\hline 77 & Crushed pruning olive tree & $30 / 04 / 2016$ & 121 & $22 \%$ & 69 & 808 & 4398,6 \\
\hline 78 & Pre-Crus. pruning olive tree & $23 / 05 / 2016$ & 415 & $16 \%$ & 38 & 926,16 & 4411,3 \\
\hline 79 & Pre-Crus. pruning olive tree & $27 / 05 / 2016$ & 433 & $17 \%$ & 38 & 761,9 & n.a \\
\hline 80 & Crushed pruning olive tree & $23 / 05 / 2016$ & 28 & $20 \%$ & 68 & 728,42 & 4614,1 \\
\hline 81 & Crushed pruning olive tree & $2 / 6 / 2016$ & 315 & $10 \%$ & 48 & 1543,62 & 4442,1 \\
\hline 82 & Pre-Crus. pruning olive tree & $12 / 5 / 2016$ & 350 & $23 \%$ & 39 & 1506,02 & 4230,9 \\
\hline 92 & Pre-Crus. pruning olive tree & $27 / 06 / 2016$ & 305 & $15 \%$ & 32,1 & 185,28 & 4603,4 \\
\hline 116 & Pre-Crus. pruning olive tree & $4 / 11 / 2016$ & 122 & $41 \%$ & 80 & 1355,36 & 4761,8 \\
\hline 117 & Pre-Crus. pruning olive tree & $22 / 12 / 2016$ & 90 & $36 \%$ & 60 & 2278,58 & 5138,8 \\
\hline 120 & Pre-Crus. pruning olive tree & $24 / 01 / 2017$ & 69 & $25 \%$ & 60 & 1435,28 & 4716,5 \\
\hline 124 & Crushed pruning olive tree & $21 / 02 / 2017$ & 187 & $29 \%$ & 74 & 462,64 & 4559,5 \\
\hline 125 & Crushed pruning olive tree & $7 / 3 / 2017$ & 210 & $22 \%$ & 75 & 1248,8 & 4596,9 \\
\hline 127 & Pre-Crus. pruning olive tree & $9 / 1 / 2017$ & 272 & $20 \%$ & 47,8 & 3661,28 & 4847,8 \\
\hline 128 & Crushed pruning olive tree & $27 / 03 / 2017$ & 195 & $20 \%$ & 74,6 & 1284,88 & 4695,2 \\
\hline 129 & Pre-Crus. pruning olive tree & $3 / 4 / 2017$ & 25 & $18,65 \%$ & 65 & 439,28 & 4379,9 \\
\hline 130 & Crushed pruning olive tree & $10 / 4 / 2017$ & 38 & $19 \%$ & 55 & 1272,14 & 4541,5 \\
\hline 133 & Pre-Crus. pruning olive tree & $20 / 04 / 2017$ & 158 & $16 \%$ & 45,1 & 572,18 & 4534,5 \\
\hline 135 & Pre-Crus. pruning olive tree & $25 / 04 / 2017$ & 151 & $12 \%$ & 63 & 585,6 & 4244,0 \\
\hline
\end{tabular}

\section{Crushed pruning of olive tree}

The crushed pruning of olive tree is a by-product with high herbaceous content and small granulometry. These characteristics favours self-heating and fermentation. The storage of this kind of biomass must be carefully controlled since its state and progression will depend much on the initial conditions of humidity and size.

After carrying out the tests and trials with this product, the following observations were obtained: 
a) Biomasses with initial humidity above $20 \%$ generate temperature increases above $80^{\circ} \mathrm{C}$. While a lower initial humidity allows the storage of larger stockpiles, without exceeding 1,000 1,200 tons.

b) After two months of storage, the rate of moisture loss is considerably reduced.

c) The larger the piles are the higher temperature is reached inside. Thus, in stockpiles larger than 800 Tons, the rate of moisture loss is reduced and the inner temperature increases. In large stockpiles, as the temperature increases there is degradation of the biomass, which is checked with the decrease of the higher heating value.

d) Small and high moisture piles lose a lot of weight in a short time due to drying and moisture losses. This weight loss is not proportional to the calorific power gain so the energy balance may be negative.

e) Small granulometry implies less moisture loss and less cooling of the collection.

f) The herbaceous composition of the product increases the action of bacteria, i.e. fermentation.

\section{Pre-Crushed pruning of olive tree}

This biomass, which has a larger granulometry than the previous one, must be crushed for final use just before consumption or final use. The global mean temperature is ten degrees lower than the one of crushed pruning biomass.

A number of observations have been made of the tests carried out with this type of product:

a) Stockpiles with humidity values below 15\% hardly lose any additional humidity, while for piles with humidity values above $20-25 \%$ the loss of humidity during storage is quite large. In large stockpiles, the rate of moisture loss is reduced, while in stockpiles of between 800 and 1,000 tons the rate of moisture loss is higher the higher the initial humidity is. The rate of moisture loss decreases as the storage duration increases.

b) In large piles, the temperature increase to almost $80^{\circ} \mathrm{C}$ while in smaller piles the temperature does not exceed $60^{\circ} \mathrm{C}$.

c) In smaller stockpiles, the degradation is much less than in larger ones, although in general the degradation that occurs in this product with this granulometry is very low, unless it is stored for a long time or is very wet.

d) If stored for more than one month after being crushed, problems of fermentation and self-heating may occur if the humidity is not completely low (Parechyma).

e) The entry of air into the collection is much easier due to its higher granulometry, so the aeration is much higher. This allows the accomplishment of bigger stockpiles. f) It is very difficult for self-heating to occur, but when it does, it is very dangerous as it has a large air inlet into the stockpile, which intensifies the spontaneous combustion process.

\section{Conclusion}

The use and storage of biomass for energy generation is a sustainable practice, as long as appropriate methods and controls are used. The action to be taken on biomass during the storage process, from start to finish, will depend mainly on the physicalchemical characteristics that the product is collected with.

Most of the studies agree that biomass moisture content is the most important characteristic as a crucial factor that generates temperature increases within the stockpile, putting at risk the quality of the biomass during storage.

Depending on the moisture content of the stored biomass, the effect generated on the stockpiles can have different behaviours. If the initial humidity is high, more heat is generated inside the pile and, therefore, the temperature increases. Moreover, this increase in temperature is a determining factor in internal reactions and risk of self-ignition. It also increases, with humidity, the degradation produced by the action of bacteria, fungi and microorganisms, in addition to that produced by chemical reactions at high temperature.

Stockpile size is another critical factor. Wet biomasses should not be stored in large piles because, in this case, the airflow is lower and the dissipation of heat generated inside decreases and favours the action of microorganisms and the self-heating. On the other hand, a cold environment and good air circulation may prevent the accumulation of heat and may help to minimize bacterial activity and self-ignition risks.

With respect to granulometry, the presence of small biomass particles favours an increase in humidity compared to environmental conditions. While larger particles favour drying and reduction of moisture content. Different behaviour of crushed pruning and pre-crushed pruning of olive tree in storage tests clearly shows the granulometry influence.

Biomass is easily degradable, especially such kind of biomass whose herbaceous component is greater. The combination of high herbaceous content and high moisture content makes the action of bacteria, fungi and microorganisms increase greatly, significantly affecting the quality of the biomass.

Regarding microbial action, it is necessary to take into account other factors: hardwoods are easier to decompose by bacteria and generate more moisture during decomposition; leaves, foliage and bark have a high content of nutrients and minerals that promote microbial activity; the activity of fungi is greater in stockpiles of chips and this activity contributes to the increase in temperature. In addition, microbial activity in biomasses with large particles is low, but when initiated it spreads rapidly. 
Hence, optimal size and type of storage is determined primarily by the combination of moisture and biomass granulometry. For biomasses with small granulometry, high herbaceous content and high humidity, small stockpiles are recommended because in these cases, small granulometry generates more compaction, less permeability and less dissipation of the heat released. On the other hand, the pile size affects self-heating as it reduces airflow in larger piles, while the use of biomasses with large particles reduces the risk of self-heating.

The tests that have been carried out with olive tree biomass, in different configurations of stockpiles and durations, confirm these results. In the case of crushed pruning of olive tree, which is a biomass with a high herbaceous content and small granulometry, the temperature increases are very dependent on the initial humidity. When it exceeds $20 \%$ there have been very significant increases in temperature, exceeding $80^{\circ} \mathrm{C}$ inside the pile, which has favoured self-heating and fermentation. The global mean temperature is ten degrees higher than the one of pre-crushed pruning biomass.

In the case of pre-crushed pruning of olive tree, which is a biomass with greater granulometry, temperature increases, and degradation are lower. In large stockpiles, the temperatures have not exceeded $80^{\circ} \mathrm{C}$, while in smaller stockpiles the temperature does not exceed $60^{\circ} \mathrm{C}$. In addition, the degradation that occurs in this product with this granulometry is generally quite low unless it is stored for a long time or is very wet. As the inlet of airflow into the stockpile is easier due to its higher granulometry, aeration is higher and it allows the formation of larger stockpiles and reduces the risk of self-ignition.

\section{Authors' Contribution}

All authors contributed to the study conception and design. Material preparation, data collection and analysis were performed by Lara Chaves, P.J. and Terrados Cepeda, J. The first draft of the manuscript was written by Lara Chaves, P.J and it was refined by Terrados Cepeda, J. Hermoso Orzáez, M.J. and Gallego Álvarez F.J. All authors commented and discussed on previous versions of the manuscript. All authors read and approved the final manuscript.

\section{References}

1. Alakoski E, Jämsén M, Agar D, Tampio E, Wihersaari M (2016) From wood pellets to wood chips, risks of degradation and emissions from the storage of woody biomass - A short review. Renew Sustain Energy Rev 54: 376-383.

2. Emery I, Dunn JB, Han J, Wang M (2015) Biomass Storage Options Influence Net Energy and Emissions of Cellulosic Ethanol. Bioenergy Res 8: 590-604.

3. Gonzalez R, Treasure T, Wright J, Saloni D, Phillips R, et al. (2011) Exploring the potential of Eucalyptus for energy production in the Southern United States: Financial analysis of delivered biomass. Part I. Biomass and Bioenergy 35(2): 755-766.
4. Gautam S, Pulkki R, Shahi C, Leitch M (2012) Fuel quality changes in full tree logging residue during storage in roadside slash piles in Northwestern Ontario. Biomass and Bioenergy 42: 43-50.

5. Pettersson M, Nordfjell T (2007) Fuel quality changes during seasonal storage of compacted logging residues and young trees. Biomass and Bioenergy 31(11-12): 782-792.

6. Eriksson A (2011) Energy efficient storage of biomass at Vattenfall heat and power plant. pp. 1-65

7. Pari L, Civitarese V, Giudice A del, Assirelli A, Spinelli R, et al. (2013) Influence of chipping device and storage method on the quality of SRC poplar biomass. Biomass and Bioenergy 51: 169-176.

8. Hogland W, Marques M (2003) Physical, biological and chemical processes during storage and spontaneous combustion of waste fuel. Resour Conserv Recycl 40(1): 53-69.

9. Ortiz L, Tejada A, Vázquez A Aprovechamiento de la biomasa forestal producida por la Cadena Monte-Industria. Rev CIS-Madera, pp. 17-32.

10. Krzyżaniak M, Stolarski MJ, Niksa D, Tworkowski J, Szczukowski S (2016) Effect of storage methods on willow chips quality. Biomass and Bioenergy 92: 61-69.

11. Gold S, Seuring S (2011) Supply chain and logistics issues of bio-energy production. J Clean Prod 19(1): 32-42.

12. Emery IR, Mosier NS (2012) The impact of dry matter loss during herbaceous biomass storage on net greenhouse gas emissions from biofuels production. Biomass and Bioenergy 39: 237-246.

13. Thornley P (2008) Airborne emissions from biomass-based power generation systems. Environ Res Lett 3.

14. Rentizelas AA, Tatsiopoulos IP, Tolis A (2009) An optimization model for multi-biomass tri-generation energy supply. Biomass and Bioenergy 33(2): 223-233.

15. Pari L, Scarfone A, Santangelo E, Figorilli S, Crognale S, et al. (2015) Alternative storage systems of Arundo donax L. and characterization of the stored biomass. Ind Crops Prod 75: 59-65.

16. Nurmi J (1999) The storage of logging residue for fuel. Biomass and Bioenergy 17(1): 41-47.

17. Nurmi J (2014) Changes in volumetric energy densities during storage of whole-tree feed stocks from silvicultural thinnings. Biomass and Bioenergy 61: 114-120.

18. Ramírez Á, García-Torrent J, Tascón A (2010) Experimental determination of self-heating and self-ignition risks associated with the dusts of agricultural materials commonly stored in silos. J Hazard Mater 175(1-3): 920-927.

19. Lin Y, Pan F (2013) Effect of In-Woods Storage of Unprocessed Logging Residue on Biomass Feedstock Quality. For Prod J 63(3-4): 119-124.

20. Yasuhara A, Amano Y, Shibamoto T (2010) Investigation of the selfheating and spontaneous ignition of refuse-derived fuel (RDF) during storage. Waste Manag 30(7): 1161-1164.

21. Hakkila P (2006) Factors driving the development of forest energy in Finland. Biomass and Bioenergy 30(4): 281-288.

22. Towey R, Webster K, Darr M (2019) Influence of Storage Moisture and Temperature on Lignocellulosic Degradation. Agri Engineering 1(3): 332-342.

23. Kadioğlu Y, Varamaz M (2003) The effect of moisture content and airdrying on spontaneous combustion characteristics of two Turkish lignites. Fuel 82(13): 1685-1693. 
24. Moqbel S, Reinhart D, Chen RH (2010) Factors influencing spontaneous combustion of solid waste. Waste Manag 30(8-9): 1600-1607.

25. Slaven I, Haviarova E, Cassens D (2011) Properties of Wood Waste Stored for Energy Production. Purdue Univ Purdue Ext 4.

26. Zanetti M, Costa C, Greco R, Grigolato S, Aalmo GO, et al. (2017) How wood fuels' quality relates to the standards: A class-modelling approach. Energies 10(10): 1-14.

27. Ferrero F, Lohrer C, Schmidt BM, Noll M, Malow M (2009) A mathematical model to predict the heating-up of large-scale wood piles. J Loss Prev Process Ind 22(4): 439-448.

28. Thörnqvist T (1985) Drying and storage of forest residues for energy production. Biomass 7(2): 125-134.

29. Afzal MT, Bedane AH, Sokhansanj S, Mahmood W (2010) Storage of comminuted and uncomminuted forest biomass and its effect on fuel quality. BioResources 5(1): 55-69.

30. Krigstin S, Wetzel S, Jayabala N, Helmeste C, Madrali S, et al. (2018) Recent health and safety incident trends related to the storage of woody biomass: A need for improved monitoring strategies. Forests 9(9): 538

31. Ashman JM, Jones JM, Williams A (2018) Some characteristics of the self-heating of the large-scale storage of biomass. Fuel Process Technol 174: 1-8.

32. Anheller M (2009) Biomass losses during short-term storage of bark and recovered wood. Dep Energy Technol Uppsala Swedish Univ Agric Sci, pp. 1-66.

33. Buggeln R (1999) Outside storage of wood chips.

34. Gislerud O, Gronlien H (1977) Storage of whole tree chip.pdf. 41.

35. Löwegren G, Jonsson L (1987) Storing of chipped logging residues and chipped oak stemwood in big piles.

36. Blomqvist P, Persson B (2003) Spontaneous Ignition of Biofuels A Literature Survey of Theoretical and Experimental Methods. SP Sveriges Provnings- och Forskningsinstitut 18: 1-33.

37. Jones JC (2000) Commentary on the UN Test for Spontaneous Heating of Solid Substances. J Loss Prev Process Ind 13: 177-178.

38. Garstang J, Weekes A, Poulter R, Bartlett D (2002) Identification and characterisation of factors affecting losses in the large-scale, nonventilated bulk storage of wood chips and development of best storage practices.

39. López Vicens I (2008) Evolución de pilas de astilla forestal bajo dos coberturas diferentes al aire libre: experiencia en alp (gerona). Boletín del CIDEU 5. Cent. Tecnològic For. Catalunya, pp. 85-95.
40. Ernstson ML, Rasmuson A (1992) Field and laboratory measurements of the air permeability of chipped forest fuel materials. Fuel 71(8): 963-970.

41. Fuller WS (1985) Chip pile storage-a review of practices to avoid deterioration and economic losses. Tappi J 68: 48-52.

42. IEA (2013) Health and Safety Aspects of Solid Biomass Storage. IEA Bioenergy.

43. Ramírez Á, García-Torrent J, Aguado PJ (2009) Determination of parameters used to prevent ignition of stored materials and to protect against explosions in food industries. J Hazard Mater 168(1): 115-120.

44. Pecenka R, Lenz H, Idler C, Daries W, Ehlert D (2014) Development of bio-physical properties during storage of poplar chips from 15 ha test fields. Biomass and Bioenergy 65: 13-19.

45. Eslyn WE (1967) Outside Storage of Hardwood Chips in the Northeast. J Tech Assoc Pulp Pap Ind 50: 297-303.

46. Palmero Palmero R (2010) Elaboracion-De-Compost-Con-RestosVegetales-1.Pdf. Agro Cabil.

47. López I (2008) Evolución de pilas de astilla forestal bajo dos coberturas diferentes al aire libre: experiencia en Alp (Gerona). Cent. Tecnològic For. Catalunya, Boletín del CIDEU 5: 85-95.

48. Jirjis R (1995) Storage and drying of wood fuel. Biomass and Bioenergy 9(1-5): 181-190.

49. Centre NI (2008) NT METHOD Guidelines for storing and handling of solid biofuels. 18 .

50. Gislerud 0 (1990) Drying and storing of comminuted wood fuels. Biomass 22(1-4): 229-244.

51. Röser D, Mola-Yudego B, Sikanen L, Prinz R, Gritten D, et al. (2011) Natural drying treatments during seasonal storage of wood for bioenergy in different European locations. Biomass and Bioenergy 35(10): 4238-4247.

52. He X, Lau AK, Sokhansanj S, Lim CJ, Bi XT, et al. (2012) Dry matter losses in combination with gaseous emissions during the storage of forest residues. Fuel 95: 662-664.

53. Ruiz-Arias JA, Terrados J, Pérez-Higueras P, Pozo-Varquez D, Almonacid $G$ (2012) Assessment of the renewable energies' potential for intensive electricity production in the province of Jaén, southern Spain. Renew Sustain Energy Rev 16(5): 2994-3001.

54. Terrados J, Almonacid G, Pérez-Higueras P (2009) Proposal for a combined methodology for renewable energy planning. Application to a Spanish region. Renew Sustain Energy Rev 13(8): 2022-2030.

\section{Your next submission with Juniper Publishers will reach you the below assets}

- Quality Editorial service

- Swift Peer Review

- Reprints availability

- E-prints Service

- Manuscript Podcast for convenient understanding

- Global attainment for your research

- Manuscript accessibility in different formats ( Pdf, E-pub, Full Text, Audio)

- Unceasing customer service

Track the below URL for one-step submission https://juniperpublishers.com/online-submission.php 